\title{
SOCIAL PARTICIPATION IN RURAL AREAS BASED ON THE EXAMPLE OF LOCAL ACTION GROUPS IN MAŁOPOLSKIE VOIVODESHIP
}

\begin{abstract}
The territorial approach to development widely recognised in the European Union and in Poland makes it necessary to form and support territorial structures based on cooperation, capable of identifying their own resources, of establishing and accomplishing common objectives. Another essential aspect seems to be the ability to establish different kinds of cooperation depending on available opportunities, needs and chances. In this context the issue of social participation takes on a new significance. In Poland social participation and partnership only recently became essential elements of planning development at all local administration levels. Local action groups are a component of institutional infrastructure in rural areas whose main purpose is to stimulate bottom-up approach to development.

The aim of the paper was to identify the forms and methods of engaging local communities in action aimed at development of a region, recognise groups that are eager to cooperate and identify barriers.
\end{abstract}

Keywords: social participation, rural areas, local action groups.

\section{Streszczenie}

\section{Partycypacja społeczna na obszarach wiejskich na przykładzie lokalnych grup działania w województwie małopolskim}

Uznane powszechnie w krajach Unii Europejskiej, w tym także w Polsce, terytorialne podejście do rozwoju rodzi konieczność kształtowania i wspierania struktur terytorialnych opartych na współpracy, zdolnych identyfikować własne zasoby, wytyczać i realizować wspólne cele. Istotną wydaje się także umiejętność zawiązywania różnego rodzaju form współpracy w zależności od pojawiających się możliwości, potrzeb czy też szans do wykorzystania. Z tego też powodu problem partycypacji społecznej także zyskuje na znaczeniu. W Polsce kwestia partycypacji społecznej, partnerstwa i współpracy od stosunkowo niedługiego czasu stanowi ważny element planowania rozwoju na wszystkich szczeblach administracji terytorialnej. Lokalne grupy działania stanowią element infrastruktury instytucjonalnej na obszarach wiejskich, któ- 
rego głównym celem jest właśnie pobudzanie oddolnego podejścia do rozwoju, co w praktyce oznacza projektowanie działań na rzecz rozwoju terytorium w oparciu o jego zasoby z możliwie jak największym udziałem lokalnej społeczności. Celem opracowania była identyfikacja form i metod jej angażowania w działania na rzecz rozwoju obszaru, rozpoznanie tych grup, które najchętniej podejmują współpracę, oraz wskazanie barier, jakie ją ograniczają.

Partycypacja społeczna na obszarach wiejskich na przykładzie lokalnych grup działania w województwie małopolskim

Słowa kluczowe: partycypacja społeczna, obszary wiejskie, lokalne grupy działania.

\section{Introduction}

Thecurrently followed by the European Union and member states, including Poland, based on a territorial approach to development presents a great deal of challenges before public administration bodies and local communities in a broad sense, which, as it seems, largely determine the developmental success of their region. Development that draws, first and foremost, on functional areas under which visions, priorities and objectives of development are formulated in accordance with specific conditions, which are not necessarily reflected in administrative borders of territorial units, requires effective mechanisms of cooperation between local authorities at various levels and local entities. The efficiency of aconsistent with the paradigm of local development seen as bottom-up development triggered by local actors - their ambitions and capabilities, will be contingent on the resourcefulness of local communities, their ability to trigger dynamic development based mainly on their own resources. The definition of resources can be quite broad. They can refer to geographical area, tangible property located within that area as well as social and institutional capital. Identification and efficient use of available resources, understood also as endogenous potential, require skilful public governance. One of its crucial elements is effective institutional infrastructure, that is, a system of local entities that cooperate with one another in the interest of common development through specific behaviours, customs, means of communication. The cooperation between local partners can take various forms and cover many fields of operation.

Local action groups operating in the European Union are a tool designed for implementation the LEADER approach in rural areas. The main objective in this approach is to support bottom-up initiatives for development of rural areas, activate and integrate local communities that should initiate developmental actions based on local resources. This is why local action groups operating on the basis of agreements (in Poland they operate as associations) of private, public and social partners are currently an essential component of institutional infrastructure in rural areas. It should be underlined that now the LAGs in Poland are one of the most significant forms of collaborative decision-making in rural areas. They usually associate local authorities, nongovernmental organizations, public organizations, private entities. There are no other institutional forms constituted by low engaging so many local partners. 
There are significant differences in both conditions and the level of development of rural areas in Poland caused mainly by historical and geographical factors. It means that the ability to pursue coherent policies is to a large extent limited. There is thus a strong need to implement policies adapted to local conditions which should be implemented by local actors (local authorities, citizens, public organizations and private entities). It must be underlined that in Poland (being one of the post-socialist country) there are no traditions in creating bottom-up development policies. Another problem in rural areas in Poland is a very low level of human capital that might create some difficulties for the process of collective learning.

The above observations were the principal reason for the choice of the subject of the paper. Another essential fact is that the majority of local action groups have recently adopted new strategies for development, according to the new requirements that put even greater pressure on socialisation. The main aim of the paper is to identify the main forms and methods of engaging local communities in territorial development and to identify groups that are most interested in the issue. Another aim of the paper is to identify barriers that hinder involvement of local communities in rural areas in the decisions concerned with the development of their region.

For the purpose of the study the author analysed new local development strategies adopted by the local action groups in Małopolskie Voivodeship that were available on their websites and conducted a telephone interview with twenty representatives of local action groups in the region.

\section{Territorial nature of socio-economic development}

Contemporary concepts of regional development are characterised by strong orientation towards the territorial factor of development. This means that the development applies to a specific geographical, social and economic area, and its level and pace hinge on the endogenous potential of that area. It should be stressed that endogenous potential only creates opportunities for development and can determine its future directions. Endogenous potentials can be activated and become an engine for local development. Generally speaking the sine qua non factor for that are effective mechanisms of cooperation among local partners supported by local authorities, able to recognize these potentials and work on common purposes.

According to contemporary views on territorial development, its main driving factor is believed to be the activation of endogenous potential of development. The main purpose of this activation is to trigger lasting dynamics of local development [Pietrzyk, 2001: 32]. In such an approach to the development issue a concept of local development seems to fit into its main assumptions. The concept of local development here does not entail reduction of the scale of a territory, but it is understood as actions taken by local actors, in light of conditions for development found in a given territory. ,Endogenous development model guarantees autonomy in the process of transformation of local economy, where the fundamental role in the decision-making process is played by local entities [...] it is based on the exploitation of local resources, the ability to control the accumulation process at a local 
level, control innovation and response to external stimuli" [Courlet, 1999: 32]. Therefore, local development refers to bottom-up method of triggering dynamic development, based on endogenous resources. In this context social participation in the process of decision-making is gaining in importance. X. Greffer believes that local development consists in enhancing business and social activities within a territory through activation and exploitation of own resources and energy. Local development takes place thanks to the efforts of local communities. Therefore, the aspirations and capabilities of a local community and mutual interaction within that community form the main factor of local development viewed as above. According to J.L. Guigou [1984: 4], local development is an effect of social solidarity that gives rise to new social relations and it determines their willingness to value local resources, which leads to economic development.

\section{The role of social participation in the process of managing territorial development}

Social participation in its traditional meaning refers to involvement of a local community in the making of decisions concerned with formulation and implementation of publicthrough actions such as: lobbying, written submissions, writing petitions, letters addressed to authorities, participation in meetings with representatives of authorities. In a contemporary approach to participation, special attention is given not only to involvement of local communities in formulating public policies, but also to their engagement in the process of realizing local strategies. In this sense, social participation is an element of modern management. It has taken on new significance when new public management concepts appeared. Currently, seeing the large number of varieties of the approach, the involvement of local communities in the decision-making process and implementation of policies plays a crucial role. The key advantages of social involvement mentioned in source literature include [Ostaszewski, 2013: 25-26]:

- development of citizenship,

- development of human potential,

- reinforcement of the spirit of civic participation,

- preventing social alienation,

- legitimization of decisions of public authorities,

- it brings people closer to the actions of authorities.

From the point of view of efficiency of decisions taken in conjunction with local communities (according to an approach to development based on partnership) the most important advantages include [Zmyślony, 2008: 68-70]:

- introduction of individual knowledge, experience, capital, administrative privileges into the cooperation,

- combining resources and actions to secure new sources of capital, identification and elimination of risks for planned actions through engagement of multiple entities, 
- introduction of new ideas for development thanks to socialisation of planning,

- increased social acceptance of planned and implemented change.

Major drawbacks concerning the efficiency of decisions taken by local communities in the area of public governance include [Ostaszewski, 2013: 26]:

- in the majority of cases - selfish and passive attitude to public affairs,

- lack of time and appropriate qualifications required to take effective decisions,

- the authority should be given to a well-qualified elite,

- excessive civic engagement can give rise to conflicts and, in effect, dysfunctions.

The need to strengthen the participation of the local communities in the decision-making process, in the case of Poland, has derived primarily from the regulations of the European Union. Now certain regulations concerning these issues are included in national documents. One of them is the National Strategy for Regional Development for 2010-2020: Regions, Cities, Rural Areas. The new approach to territorial development, concerning participation aspects, has been introduced in this document as a new regional policy. It has been based on a few fundamental assumptions [Noworól, 2013: 72-74]. Firstly, it takes into account the territorial consequences of new socio-economic challenges associated with events, such as: globalisation, negative demographic changes, climate change. Secondly, it takes into account endogenous potential for development of a territory. Thirdly, there is a clear pressure on a strategic approach to development, which consists in concentration on key priorities and efficient management of such priorities. One should note that the above-mentioned fundamental assumptions of the paradigm of new regionalare related with the need for socialisation of the process of formulating development strategies, and, above all, the identification of resources and establishment of common objectives of development. There are also legislative acts (e.g. Act of 20 February 2015 on local development involving local communities).

Above findings lead to a conclusion that local authorities should promote social participation in the process of territorial development. Unfortunately, for many reasons, this level of participation is insufficient and often comes down only to carry out the legally required procedures [Hołuj, 2016: 115-116].

\section{Local action groups as an element of institutional infrastructure in rural areas}

One of the forms of territorial cooperation in rural areas is a local action group. Local action groups constitute an example of cross-sectoral partnership (established by social, public and private entities) and they emerged as a tool for implementation of EUin rural areas under the LEADER programme. In Poland the programme was launched in 2004 as one of the instruments of a sectoral operational programme: Restructuring and Modernisation of the Food Sector and Rural Development for 2004-2006. In the following financial perspective of the EU the 
programme constituted one of the axes of the Rural Development Programme for 2007-2013. Since 2014 local action groups have operated under the regulations that govern the new approach to territorial development - local development with involvement of local communities, which supports bottom-up initiatives of local entities in a comprehensive and integrated manner. ${ }^{1}$ Their work may be co-financed with structural funds, funds from the European Agricultural Fund for Rural Development or European Fund for Strategic Investments. In reality, operations of local action groups cover several rural or rural-urban municipalities whose total population should not exceed 30,000. Local action groups carry out their tasks on the basis of the provisions of local development strategies (LDS) formulated in light of specific conditions present in the areas that they cover. Local development strategies should have a bottom-up character, meaning that they should be formulated and implemented with the participation of a local community. The majority of local action groups in Poland have started fulfilment of the second round of the strategy covered by the EU's budget for 2014-2020. The stages and methods of social participation in the process of formulating strategies have been formulated in detail under guidelines for local action groups [Poradnik dla lokalnych grup działania..., 2015].

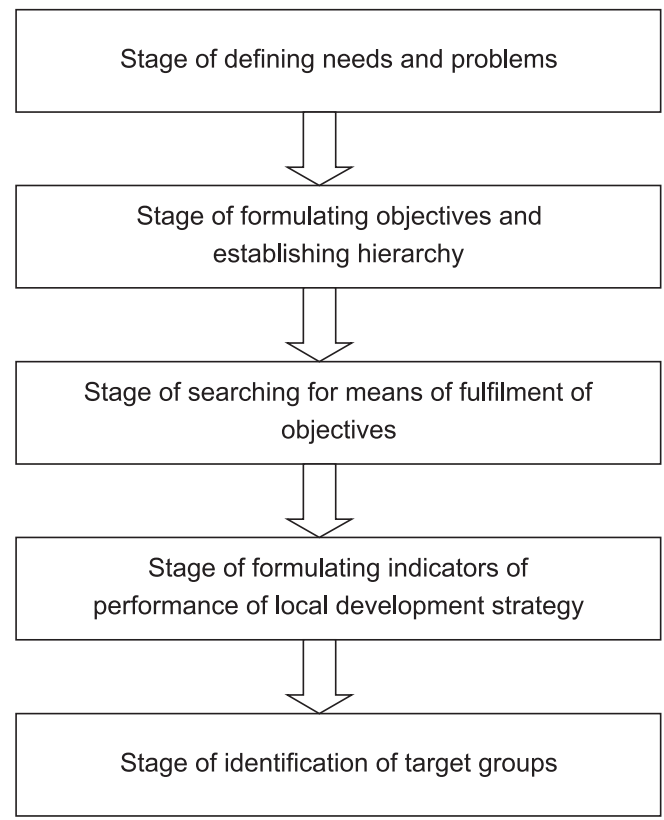

Figure 1. Stages of formulation of local development strategies that ensure involvement of local communities

Source: work based on Poradnik dla lokalnych grup działania ..., 2015: 19-20.

${ }^{1}$ In 2014-2020 the operation of local action groups is governed by the Act of $20^{\text {th }}$ February 2015 on local development involving local communities. 
According to the provisions of the Act of $20^{\text {th }}$ February 2015 on local development governed by local communities, one of the key rules of operation of local action groups is the participatory nature of their policies. This is reflected in the formula of the process of formulating and implementing the said development strategies. Formulating at each stage, from identification of the conditions specific for a given area, through establishment of priorities and objectives of development and formulation of indicators. Another element that plays a fundamental role in socialisation of the process of formulating strategies is the identification of target groups to whom planned actions are addressed. The purpose is to reach appropriate circles of people and engage them in cooperation in the area of adjusting interventions to their concrete needs and possibilities.

European researchers agree that the LEADER approach is an important tool to deal with local development problems in rural areas. They underline it's role in integrating local society on the real development problems. The social integration allows to exchange experience, learn new skills, believe in own abilities which in effect enables to build local identity and generate local development based on endogenous potential [Zajda, Sykała, Janas, Dej, 2017: 37-40; Buller, 2000: 190-199; Bruckmeier, 2000: 219-227]. However, there are also some research revealing certain weaknesses of the LEADER approach. A. Krievina, I. Leimane, L. Melece point out that one of the main problems of implementing the LEADER in Latvia is that people are ill-informed about the activities of $L A G$ and are not familiar with the LDS developed by them [2015: 147-148]. The same Authors mention the European Court of Auditors opinion about the contents of the Local Development Strategies (2007-2013), where goals based on certain conditions of a territory are missing, thus the expected results have been defined incompletely. One of the reason for such a situation might be lack of prior experience in cooperation among different local partners aimed at achieving development goals, insufficient legal frameworks on the national levels, weaknesses of project management, insufficient promotion of the action provided by the LAGs [Brańka, 2015: 498-499]. The national aspects of functioning of the Local Action Groups are thus different and they result from the variety of economical and social conditions as well as from the prior experience in implementing local development policies based on social capital and endogenous potentials.

\section{Participation of local communities in formulation of local development strategies in light of a survey study conducted among members of local action groups in Małopolskie Voivodeship}

The main problems associated with socialisation of the process of rural development programming in Małopolskie Voivodeship were identified on the basis of:

1. analyses of adopted local development strategies available on websites of local associations - every document contains a chapter devoted to the applied methods and forms of socialisation of strategies, 
2. a telephone interview with twenty representatives of local action groups based in Małopolskie Voivodeship.

The principal aim of the study was to identify the main forms of social participation in programming of local development in rural areas, and to identify groups that readily engage in the process. Another aim of the study was to define barriers to involvement of local communities in making decisions about development of the region.

Currently, there are thirty seven local action groups in Małopolskie Voivodeship. Most of them have a new local development strategy adopted for the present EU budget period. The remaining groups are still working on their strategies. As has already been mentioned, the basis for development of a LDS is the Act on local development governed by local communities which relies on the socialised process of formulation and implementation of strategies. This is to ensure that the development of a region has a bottom-up nature, i.e. it is more efficient and adjusted to local conditions. The majority of the strategies were formulated incooperation of three groups that represent different (complementary) work methods arising from different competencies and experience. The three groups include: the experts (usually external advisors), the officials (mostly clerks) and the representatives of the local community (inhabitants, private entities, NGOs).

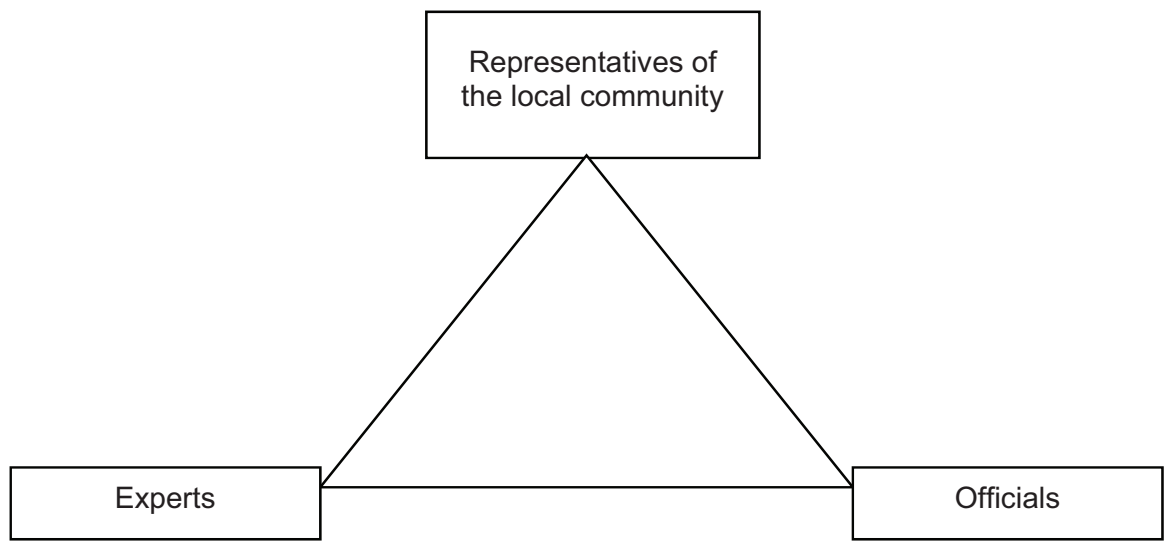

Figure 2. Groups representing different approaches to the expert-participatory method Source: own work based on Local development strategy governed by local communities for 2016-2022. LAG Blisko Krakowa 
The experts'contribution can be helpful at various stages of formulation of a strategy, e.g. performance of analyses associated with the diagnostic part, formulation of participatory methods, development of performance indicators, strategy promotion. The officials contribute to the project with specific knowledge, experience and skills of the staff of local, government and public institutions (e.g. familiarity with specific local conditions, institutional relations in the area, knowledge of procedures, financial potential). Finally, the key role of the representatives(social and public institutions, inhabitants, entrepreneurs) is exposing diverse experience, knowledge and competencies and needs of the participants. Further, it is assumed that the bottom-up nature of the approach to development will ensure that the contents of the strategy will arise from the actual needs, possibilities and aspirations of local communities, and thus they will be more compatible with local conditions.

The most common activities and techniques that might support social participation at the stage of local strategy formulation included (in all of the analysed strategies):

- electronic questionnaires,

- consultation desk at LAG's registered office,

- open access workshops addressed to the inhabitants,

- organisation of a working party composed of various representatives of local communities,

- open call for project ideas for investments that the inhabitants would like to see in the LAG area,

The less often mentioned techniques were:

- auditory survey,

- e-consultations with representatives of local action groups during which inhabitants could ask questions and express their opinions,

- social dialogue workshops that involved invited representatives of selected local communities who were supposed to voice their opinions,

- direct research (walk-through survey),

- World Cafe workshops,

- open-source intelligence,

- focus interview,

- deliberative workshops.

It is not easy to specify the involvement of local communities in particular events as some of the organisations failed to provide a number of participants in their strategies. In some cases the participants were representatives of a specific group where more people could have been involved in formulation of a strategy. The available data indicates that only $2-3 \%$ of local community took part in the survey study on the main directions for regional development. The involvement in organised workshops and meetings concerned with the principal problems of local development was even less significant - the number of participants did not exceed one hundred, usually it was much lower than that. 


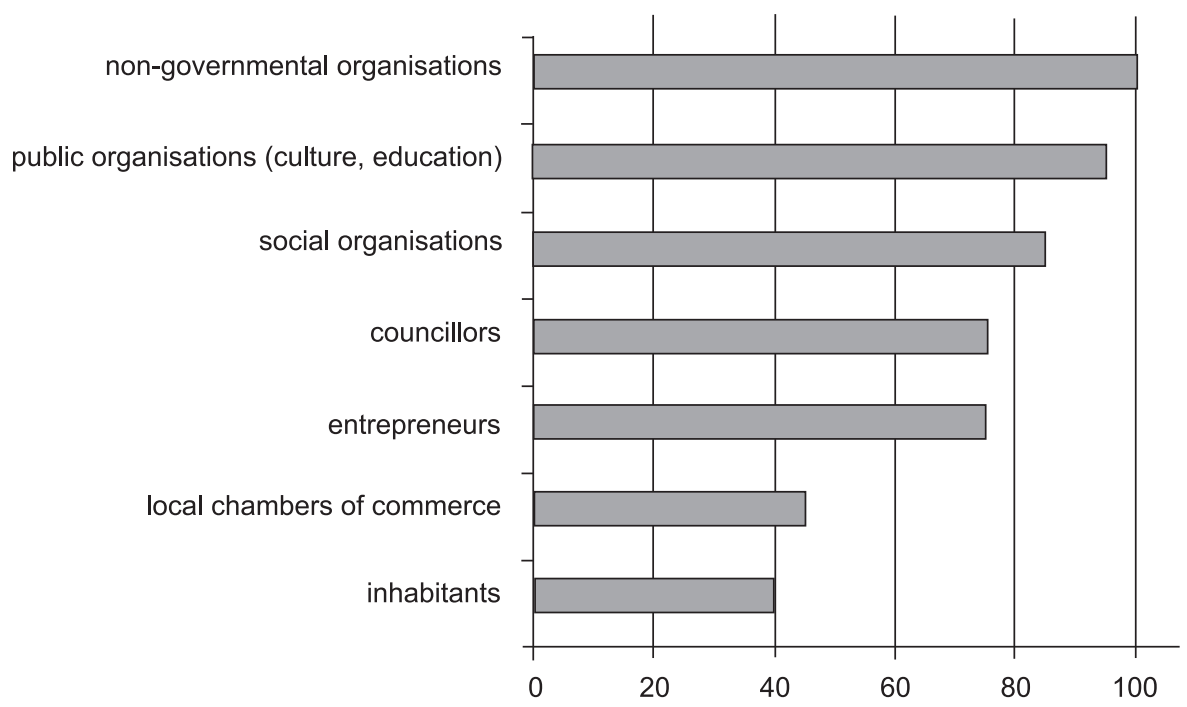

Figure 3. Main groups of local community involved in the process of formulating local development strategies in Małopolskie Voivodeship

Source: own work based on a telephone interview.

According to the respondents the parties that were most eager to take part in the process of formulating local development strategies were non-governmental organisations (all the respondents were unanimous) followed by public organisations concerned with education and culture, and social organisations. The inhabitants were a relatively less active group - according to eightout of twentyrespondents, the inhabitants were active participants of the process of formulating strategies (Figure 3). The research indicated that inhabitants and entrepreneurs were more active in places with identified local resources (usually associated with development of tourism). Moreover, it should be stressed that the interest was significantly higher (especially among the inhabitants) at the initial stages of formulation of strategies (diagnosis and establishment of general directions for development). The interest faded at later stages concerned with details of implementation of strategies. This finding reveals a kind of immaturity of local society in analysed region (Małopolska) to participate in the whole process of decision making on territorial development issues. People seem to be willing to report their expectations and ideas concerningfuture purposes for territorial development, but they are not able (or they are not interested in) to work on individual projects. To find reasons for such a situation additional researchshould be conducted. 


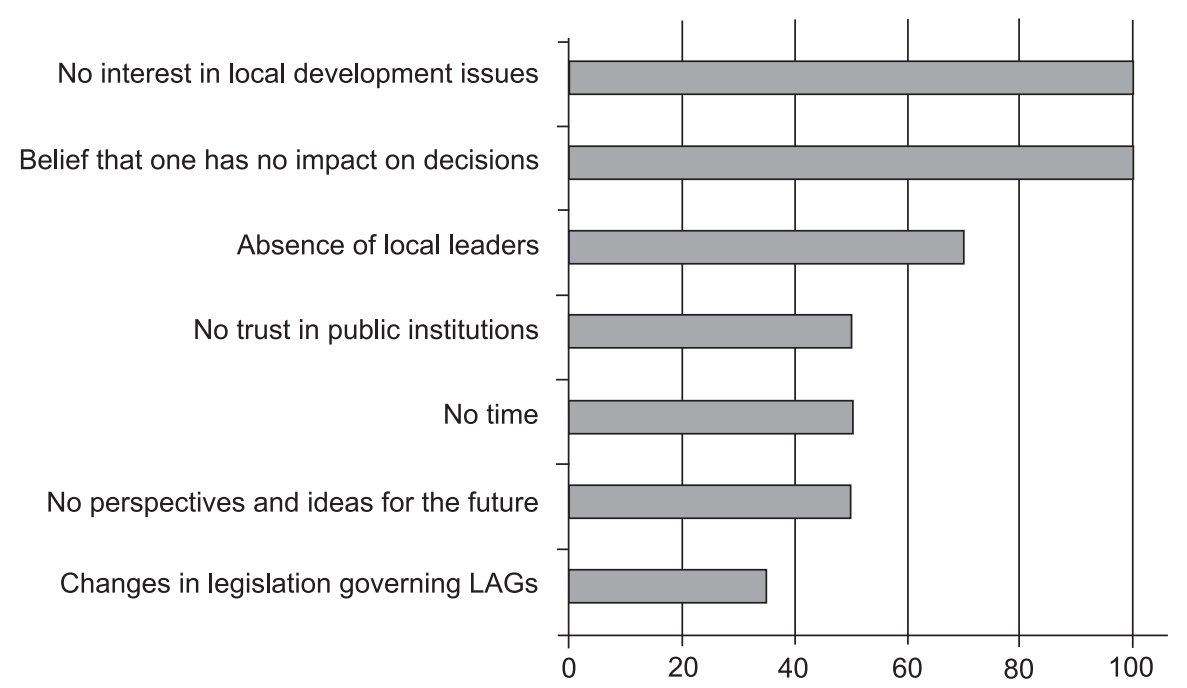

Figure 4. Main barriers to social participation in the process of formulating local development strategies

Source: own work based on telephone interviews with representatives of local action groups in Małopolskie Voivodeship.

According to the representatives of local action groups, the main barriers to social participation in the decision-making process included: no interest in local development issues (especially among the inhabitants), belief that they have no impact on future decisions. A slightly less serious problem that has been pointed out by fourteenrespondents was the absence of local leaders whose presence plays a fundamental role in stimulating activity of other local entities. Half of the respondents named the following barriers to participatory approach to local development: no time, no ideas for development and lack of trust in public institutions. Seven of the representatives pointed to the changing rules of acquiring funds from local action groups as a factor that discouraged local investors (Figure 4). The main barriers to social participation reveal some weaknesses of local societies that might have a negative impact of final effects. These weaknesses fully correspond with disadvantages of participation pointed out by K. Ostaszewski (p. 5).

\section{Conclusions}

Local action groups are one of the tools for implementation of UE in rural areas their main purpose is to activate bottom-up development based on internal resources of a territory. In rural areas in Poland, largely characterised by rich natural resources, considerable cultural heritage associated with local traditions, but also 
excessive number of agricultural workers, poor socio-economic development, including poorly developed infrastructure, and as a consequence, insufficient development of non-agricultural economic activities, local action groups are an element of institutional infrastructure that stimulates local communities to work for the benefit of territorial development. A statutory principle for their functioning is engaging local communities in the process of territorial development. This is reflected primarily in the procedure of formulation of a strategy which provides for participation of a local community at every stage.

The research led to formulation of the following conclusions. Firstly, the formula of operation of local action groups in rural areas in Poland allows for introduction of new organisational solutions. They consist primarily in initiating the cooperation between various (public, social, private) entities in the interest of common development. Due to historical events the society is Poland is only at the beginning of shaping participatory attitudes and reality shows that many people do not feel the need or desire to participate in public life. It should be noted that the ability to identify and take advantage of territorial capital is the key to efficient development of a territory. However, for this purpose one has to be capable of defining common objectives and establishing cooperation between various entities (especially cooperation on a horizontal level). This is why initiatives such as local action groups play, as the representatives believe, a fundamental role in the process of gradually learning how to cooperate in a local environment. Secondly, the scale of participation of local communities (especially the inhabitants and entrepreneurs) in the making of decisions about directions for territorial development seems to be deficient. The principal participants are non-governmental and public organisations. For this reason it is essential to take actions aimed at stimulating activity. In the respondents' opinion local leaders have a significant influence over local communities in that respect. In order to strengthen participatory attitudes of local communities it seems to be crucial to provide necessary information about advantages of this participationat the stage of early elementary education (courses, lessons, meetings, actions, events). It is also essential to shape a sense of local identity, solidarity as well as intergenerational integration which can play an important role for social cohesion and lead to efficient cooperation in the future. Some barriers that associations encountered in the process of formulating and implementing initial strategies will probably be eliminated thanks to greater experience in management, better understanding of local environment and greater trust between particular actors [cf. Brańka 2015: 493-500].

Thirdly, the actual involvement of local communities in the territorial development is evidenced by active participation in initiatives and projects that are consistent with jointly established directions for development. The research indicated that the local communities were eager to take part in works on strategies at the stage of diagnosis and establishment of directions for future development. Their involvement proved to be significantly lower at later stages which were concerned with details of operations. Taking into consideration the fact that one of the principal aims of socialisation of development programming is to increase the efficiency of performance of established objectives through a better adjustment 
to local conditions, the decreasing interest of local communities at the stage of work on detailed decisions gives rise to a question whether involvement of a community at implementation stage will be sufficient for generating a lasting effect of development.

\section{Bibliography}

Brańka P. (2015), Managing Development Based on Endogenous Potential in Rural Areas in Malopolska Region [in:] Knowledge, Economy, Society: Challenges and Trends of Modern Economy, Finance and Information Technology, A.Malina, R.Oczkowska, J.Kaczmarek (ed.), Fundacja Uniwersytetu Ekonomicznego, Kraków.

Bruckmeier K. (2000), Leader in Germany and the Discourse of Autonomous Regional Development, "Sociologia Ruralis", vol. 40, iss.2.

Buller H. (2000), Re-creating Rural Territories: LEADER in France, "SociologiaRuralis", vol. 40, iss. 4, pp. 190-199.

Cooke P., Morgan K.(1998), Associational Economies. Firms regions and innovation, Oxford University Press, Oxford.

Courlet C. (1999), Territoire et développement, "Revue d’Économie Régionale et Urbaine", iss. 3.

Guigou J.L. (1984), Le développement local, „Corespondance Mumcipale”, $\mathrm{nr} 246$.

Hołuj D. (2016), Social Participation as a Toolfor Managing Functional and Spatial Changes. Example of Selected Centres of Small and Medium-Sized Towns in Poland, Journal of Settlement and Spatial Planning, Centre for Research on Settlement and Urbanism, DOI: 10.19188/02JSSP022016 [dostęp: 07.11.2016].

Krievina A., Leimane I., Melece L. (2015), Role of Local Action Groups in Addressing Regional Development and Social Problems in Latvia, "Research for Rural Development", vol. 2, Latvia University of Agriculture, Jelgava.

Local development strategy governed by local communities for 2016-2022. LAG Blisko Krakowa

Noworól A. (2013), Ku nowemu paradygmatowi planowania lokalnego, CeDeWu.pl, Warszawa.

Ostaszewski K. (2013), Partycypacja społeczna w procesie podejmowania rozstrzygnięć $w$ administracji publicznej, Wydawnictwo KUL, Lublin.

Pietrzyk I. (2001), Zasoby specyficzne, jako determinanta konkurencyjności regionu [in:] Konkurencyjność miast i regionów a przedsiębiorczość i przemiany strukturalne, A. Klasik (ed.), Wydawnictwo Akademii Ekonomicznejw Katowicach, Katowice.

Poradnik dla lokalnych grup działania $w$ zakresie opracowania lokalnych strategii rozwoju na okres finansowania 2014-2020 (2015), Ministry of Agriculture and Rural Development, Warszawa.

Zajda K., Sykała Ł., Janas K., Dej M. (2017), Metody i instrumenty rozwoju lokalnego. LEA$D E R, R L K S$, innowacje społeczne, Akademia Samorządowa, Wydawnictwo Uniwersytetu Łódzkiego, Łódź.

Zmyślony P. (2008), Partnerstwo i przywództwo w regionie turystycznym, Wydawnictwo Akademii Ekonomicznej w Poznaniu, Poznań. 